\title{
Swiss ball to relieve pain of primiparous in active labor*
}

\author{
A bola suiça no alivio da dor de primigestas na fase ativa do trabalho de parto

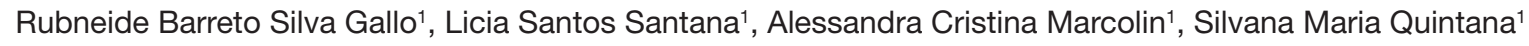

${ }^{*}$ Received from the Reference Center for Women's Health from Ribeirão Preto-Mater, Ribeirão Preto, SP, Brazil.

\section{ABSTRACT}

BACKGROUND AND OBJECTIVES: The Swiss ball has been widely used in different health sectors. It is considered effective to relieve pain and to help labor evolution, however there are few studies. This study aimed at evaluating the effect of the Swiss ball on pain relief and active labor duration of primiparous.

METHODS: This is a randomized and controlled study with 40 primiparous divided in control group and ball group, who carried out pelvic mobility exercises for 30 minutes during active labor. Pain was measured by the numeric categorical scale, before and after therapy, by an assistant researcher. Labor duration was investigated by means of the partograph.

RESULTS: There has been significant pain decrease in the study group $(\mathrm{p}<0.001)$. There has been no difference between groups in labor duration $(\mathrm{p}=0.37)$.

CONCLUSION: The Swiss ball was an effective tool to relieve pain in the beginning of this period and should be encouraged by health professionals assisting parturients.

Keywords: Labor, Pain, Swiss ball.

\section{RESUMO}

JUSTIFICATIVA E OBJETIVOS: A bola suíça tem sido amplamente utilizada nos diversos setores da saúde. É considerada eficaz no alívio da dor e evolução do trabalho de parto, porém há poucos estudos. O objetivo deste trabalho foi avaliar o efeito da bola suíça no alívio da dor e na duração da fase ativa do trabalho de parto em primigestas.

MÉTODOS: Trata-se de um estudo randomizado e controlado com 40 primigestas divididas em grupo controle e grupo bola, que realizaram exercícios de mobilidade pélvica durante 30

1. University of São Paulo, School of Medicine, Department of Gynecology and Obstetrics, Ribeirão Preto, SP, Brazil.

Submitted in February 17, 2014

Accepted for publication in September 19, 2014

Conflict of interests: none.

Correspondence to:

Rubneide Barreto Silva Gallo

Avenida Bandeirantes, 3900 - Monte Alegre

14049-900 Ribeirão Preto, SP, Brasil.

E-mail: rubneidegallo@gmail.com

(C) Sociedade Brasileira para o Estudo da Dor minutos na fase ativa do trabalho de parto. A dor foi mensurada por meio da escala de categoria numérica, antes e após a terapêutica, por um pesquisador auxiliar. A duração do trabalho de parto foi investigada por meio do partograma.

RESULTADOS: Foi observada redução significativa da dor no grupo de estudo $(\mathrm{p}<0,001)$. Náo houve diferença entre os grupos quanto à duraçáo do trabalho de parto $(\mathrm{p}=0,37)$.

CONCLUSÃO: A bola suíça foi um recurso efetivo no alívio da dor no início desse período, devendo ser incentivada pelos profissionais de saúde que assistem parturientes.

Descritores: Bola suíça, Dor, Trabalho de parto.

\section{INTRODUCTION}

The Swiss ball was developed in 1963 by Aquilino Cosani, Italian plastics manufacturer. Such name was given in 1989 by American physiotherapists after witnessing its benefits in Switzerland and starting using it in the USA. Some years ago, this tool started to be used to assist women during labor, being also called birth ball, because it helps relieving pain and the evolution of this stage ${ }^{1,2}$.

Women's habit of moving during labor and staying in the upright position was a common practice in the past. However, when delivery started to occur in the horizontal position, parturients were kept in bed, despite several published studies about the benefit of parturients' mobility and the Brazilian Ministry of Health guidance with regard to freedom of position during this period ${ }^{3,4}$. Only a small number of women started to spontaneously choose to walk or to adopt other vertical position during labor, being this especially encouraged by groups advocating labor and birth humanization.

The benefits of parturients' mobility during labor are increased tolerance to pain, decreased use of drugs, improved dilatation evolution and decreased active labor duration ${ }^{5}$. The Swiss ball, therapeutic tool commonly used in physiotherapy, was inserted in normal birth centers to help the adoption of vertical positions and to support other techniques (among them, massage and shower bath, stretching exercises and pelvic mobility ${ }^{6,7}$. For being a playful method, it distracts parturients, making labor smoother, decreasing physical and emotional stress and providing further comfort ${ }^{2,8}$.

Notwithstanding the extensive use in other health areas, there are still few studies on Swiss ball to control labor pain and evolution. In light of the above, this study aimed at evaluating the effect of the Swiss ball in pain relief and active labor stage duration of primiparous women. 


\section{METHODS}

This is a randomized controlled clinical trial developed from August 2011 to July 2012 in a maternity assisting low-risk parturients, namely the Reference Center for Women's Health of Ribeirão Preto-MATER. Sample was made up of 40 parturients divided in control group - CG (20) and ball group - BG (20).

Patients were admitted in the pre-delivery period for parturition process assistance and have met all inclusion criteria: primiparous, literate, single fetus in cephalad position, low-risk pregnancy, as from 37 weeks of gestation, cervical dilatation between 4 and $5 \mathrm{~cm}$, with adequate uterine dynamics for this labor stage of spontaneous onset, with no use of drugs, intact membranes without associated risk factors and lack of cognitive or psychiatric problems according to psychological evaluation of the institution during pre-natal assistance.

Exclusion criteria were: parturients admitted for labor induction, premature or early chorioamniorrhexis, or not using uterotonic drugs before the active stage.

After being explained about the study, only volunteers who agreed to sign the Free and Informed Consent Term (FICT) were included.

Pain intensity of all parturients was evaluated by the numeric categorical scale (NCS) and soon after they were submitted to therapy by a physiotherapist according to the group (randomly determined). BG was submitted to pelvic mobility exercises with the ball, active pelvic anteversion and retroversion exercises, lateralization, circumduction and propulsion; CG was submitted to maternity procedures with freedom of position. Both groups have carried out activities for $30 \mathrm{~min}$ utes, while with cervical dilatation from 4 to $5 \mathrm{~cm}$. All patients were evaluated by NCS after the procedure, being that pain intensity before and after the intervention was evaluated by an assistant. After intervention, labor duration, dilatation and fetal descent speed, type of delivery and Apgar score were evaluated for all patients.

Excel was used for statistical analysis and results are shown in mean and standard deviation, considering significant $\mathrm{p}<0.5$. This study was approved by the Research Ethics Committee, Clinicas Hospital, School of Medicine of Ribeirão Preto (HCFMRP) according to process HCRP no 9148/2011.

\section{RESULTS}

With regard to socio-demographic data, mean age of both groups was $19 \pm 4$ years ( $\mathrm{p}=0.81$ ); $80 \%$ of BG and $50 \%$ of CG had completed high-school ( $\mathrm{p}=0.62) ; 80 \%$ of BG and $100 \%$ of CG had no remunerated activity $(p=0.21)$; and $60 \%$ of both groups had consensual union $(\mathrm{p}=0.79)$.

All parturients had escorts during labor. Although the maternity has delivery preparation courses, no group has participated in this experience.

Analysis of results after intervention has shown significant pain decrease for BG $(\mathrm{p}<0.001)$ (Figure 1).

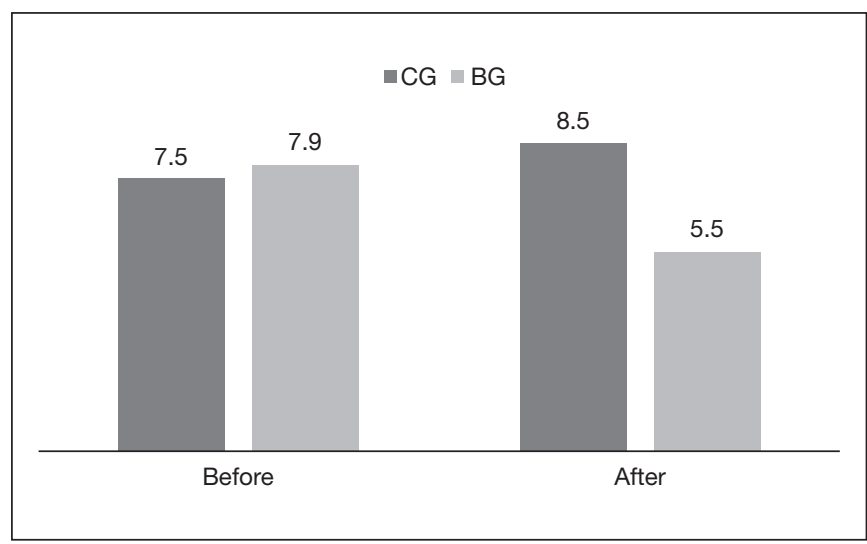

Figure 1. Pain intensity by the numeric categorical scale: comparison between studied groups

CG: control group; BG: ball group.

Labor duration was not different between groups $(\mathrm{p}=0.37)$, as well as dilatation and fetal descent speed $(\mathrm{p}=0.36)$ (Table 1).

Table 1. Analysis of labor duration and dilatation and fetal descent speed for both groups

\begin{tabular}{lllllll}
\hline \multicolumn{7}{c}{ Labor duration } \\
& $\mathrm{n}$ & Minimum & Median & SD & Maximum & $\mathrm{p}$ value \\
\hline BG & 20 & 2.75 & 6.25 & 2.53 & 10.62 & 0.37 \\
$\mathrm{CG}$ & 20 & 3.00 & 5.83 & 2.00 & 9.00 & \\
\hline \multicolumn{7}{c}{ illatation and fetal descent speed } \\
& $\mathrm{n}$ & Minimum & Median & $\mathrm{SD}$ & Maximum & $\mathrm{p}$ value \\
\hline BG & 20 & 0.45 & 1.25 & 0.43 & 1.77 & 0.36 \\
CG & 20 & 0.50 & 1.03 & 0.31 & 1.50 &
\end{tabular}

CG: control group; BG: ball group; Wilcoxon Test.

In this sample, $80 \%$ of CG and $100 \%$ of BG had normal childbirth $(p=0.47)$. As to Apgar score, 90\% of neonates of both groups had Apgar $>7$ both in the first and fifth minute, with no differences between groups $(p=0.63)$.

\section{DISCUSSION}

Some studies have shown that Swiss ball exercises are effective for dilatation evolution, pain relief and easier fetal descent. However, such information is still empirical since published studies are scarce. Adding to this, freedom of movement allows women to instinctively adopt positions that help fetal accommodation, decrease vessels and nerves pressure, and decrease pain and stress levels. In the current model of delivery assistance, present in most Brazilian maternities, this approach is made difficult. Parturients are kept in bed under oxytocites, which negatively influence women's posture during parturition.

Our study has observed that the ball was effective auxiliary tool for the adoption of vertical positions and to relieve labor pain $(\mathrm{p}<0.001)$. Leung et al. ${ }^{9}$ have evaluated a delivery room of the KwongWah hospital in Hong Kong, China, with 203 women, and have shown statistically significant differences 
in low back pain and lower abdominal pressure levels before and after birth ball exercises $(\mathrm{p}<0.05)$, as well as in stress and anxiety relief with high level of satisfaction and $6.4 \%$ decrease in the use of analgesics, as compared to two previous years of assistance in that maternity.

Still in China, Taiwan, a study carried out by Gau et al. ${ }^{10}$ has shown similar evidences added to labor duration reduction with the Swiss ball. An exercise program was recommended via a 26-page booklet and a 19-minute video and was periodically followed-up during pre-natal consultations, being that women from the experimental group have received the ball. They were encouraged to choose the most comfortable positions and to perform movements and exercises. There has been labor pain decrease, less need for epidural analgesia, decreased duration of first labor stage and fewer indications for Cesarean-section as compared to control group.

In our study, although the use of the ball has not changed labor dilatation duration and speed, this is in line with what was found by Lopes, Madeira \& Coelho ${ }^{2}$ and by Taavone et al. ${ }^{11}$; labor pain relief $(\mathrm{p}<0.05)$ and no influence on labor duration. The use of additional resources for pain relief is a very common practice in Eastern countries. In Brazil, in spite of the implementation of the National Policy for Labor and Birth Humanization, there is still a high number of C-sections, especially in the supplementary chain. Silva et al. ${ }^{7}$ have characterized the use of the Swiss ball in obstetric attention services linked to the Single Health System: it was used by $40.9 \%$ of Obstetric Centers with the following objectives: to promote fetal presentation descent (32.4\%), relaxation (19.7\%), delivery progression $(17.1 \%)$, perineal exercise $(14.5 \%)$, pain relief $(11.8 \%)$, psychological benefits and maternal movement. However, almost all visited institutions (96.8\%) had no protocol for its use, pointing to the need of clinical trials to evaluate its effects and to support the development of guidance for its use.

Interfering with normal physiological labor process increases the risk of maternal and fetal complications ${ }^{12}$. So, the Swiss ball, in addition to helping pelvic mobility and the adoption of vertical posture, may give support to other techniques during labor.

\section{CONCLUSION}

The Swiss ball was an effective resource for parturients' pain relief in the beginning of this period, and should be encouraged by health professionals assisting parturients.

\section{REFERENCES}

1. Carrière B. Bola Suíça. 2a ed. São Paulo: Manole; 1999. 383p.

2. Lopes CT, Madeira ML, Coelho S. O uso da bola do nascimento na promoçáo da posiçấo vertical em primíparas durante o trabalho de parto. Rev Min Enfermagem. 2003;7(2):134-9.

3. Bio E, Bittar RE, Zugaib M. Influência da mobilidade materna na duração da fase ativa do trabalho de parto. Rev Bras Ginecol Obstet. 2006;28(11):671-9.

4. Brasil. Ministério da Saúde. Secretaria de Políticas de Saúde. Área Técnica de Saúde da Mulher. Parto, aborto e puerpério: assistência humanizada à mulher. Brasília: Ministério da Saúde; 2001.

5. Canesin KF, Amaral WN. Atuaçāo fisioterapêutica para diminuiçāo do tempo de trabalho de parto: revisão da literatura. Femina. 2010;38(8):429-33.

6. Gallo RB, Santana LS, Marcolin AC, Ferreira, CH, Duarte, G, et al. Recursos não farmacológicos no trabalho de parto: protocolo assistencial. Femina. 2011;39(1):41-8.

7. Silva LM, Oliveira SM, Silva FM, Alvarenga MB. Uso da bola suíça no trabalho de parto. Acta Paul Enferm. 2011;24(5):656-62.

8. Baracho E. Fisioterapia aplicada à obstetrícia, uroginecologia e aspectos da mastalgia. $4^{a}$ ed. Rio de Janeiro: Guanabara Koogan; 2007. 216p.

9. Leung RW, Li JF, Leung MK, Fung BK, Fung LC, Tai SM, et al. Efficacy of birth ball exercises on labour pain management. Hong Kong Med J. 2013;19(5):393-9.

10. Gau ML, Chang CY, Tian SH, Lin KC. Effects of birth ball exercise on pain and self-efficacy during childbirth: a randomised controlled trial in Taiwan. Midwifery. 2011;27(6):293-300.

11. Taavoni S, Abdolahian S, Haghani H, Neysani L. Effect of birth ball usage on pain in the active phase of labor: a randomized controlled trial. J Midwifery Womens Health. 2011;56(2):137-40.

12. Romano AM, Lothian JA. Promoting, protecting, and supporting normal birth: a look at the evidence. J Obstet Gynecol Neonatal Nurs. 2008;37(1):94-105. 